\title{
Immunotherapy with Dendritic Cells and Newcastle Disease Virus in Glioblastoma Multiforme
}

\author{
Thomas Neßelhut ${ }^{1}$, Dagmar Marx ${ }^{1}$, Jan Neßelhut ${ }^{1}$ and Fred Fändrich ${ }^{2}$ \\ ${ }^{1}$ Institute for Tumortherapy, Duderstadt \\ ${ }^{2}$ Clinic for Applied Cellular Medicine, University of Kiel \\ Germany
}

\section{Introduction}

Malignant gliomas are the most prevalent type of primary brain tumors in adults. The most aggressive form, glioblastoma multiforme (GBM, WHO grade IV glioma), is characterized as incurable with average survivals less than 18 months (Buckner, 2003; Curran et al., 1993; De Angelis, 2001). Standard therapy consists of surgical resection to the extent that is safely feasible, followed by radiotherapy and adjuvant chemotherapy. A meta-analysis based on 12 randomized trials has supported the use of adjuvant chemotherapy treatment as compared to radiotherapy alone. A five percent increase in survival at two years, from 15 percent to 20 percent was reported (Stewart, 2002). In this context, an oral alkylating agent, temozolomide, has demonstrated antitumor activity as a single agent in the treatment of glioblastoma patients (Newlands et al., 1997; Stupp et al., 2001, 2005; Yung et al., 2000). At a median follow-up of 28 months, temozolomide treatment prolonged the median survival from 12.1 months with radiotherapy alone to 14.6 months when administered with concomitant radiotherapy (Stupp et al., 2005). Adjuvant administration of carmustine, a nitrosourea drug, has not resulted in beneficial prolongation of survival, although some long-term survivors in the chemotherapy groups have been documented in some of the nonrandomized phase III trials (Chang et al., 1983; Green et al., 1983). Despite these advances in combined radio- chemotherapy treatment strategies along with surgical resection, the prognosis of patients with malignant glioma is poor and $\geq 80 \%$ of the patients survive less than 2 years. Salvage treatments upon recurrence are palliative at best and rarely provide a significant survival benefit. The minor clinical benefit of radio-chemotherapy is supposed to be mainly based on tumour stem cells, which in analogy to normal stem cells are resistant to radio- and chemotherapy (Liu et al., 2006; Singh et al., 2003). Therefore, the development of new treatment modalities is extremely important.

It is known that defects in the immune system play a crucial role in the development of cancer as well as in the host defense against cancer. Thus, specific immune therapeutic therapy approaches have been tested for a long time. Tumor-associated antigens recognized by tumor-reactive cytotoxic T lymphocytes (CTL) have been identified during the last two decades (Janeway et al., 2004). Also in patients with GBM such tumor antigen specific CD8+ $\mathrm{T}$ cells have been identified in the circulating blood (Tang et al., 2005). A specific cancer 
immunotherapy can be based on the use of antibodies directed against specific antigens, which are expressed in tumors. However, the more recently described immunological therapy strategy for GBM with an antibody (Bevacizumab), which blocks angiogenesis by binding to the vascular endothelial growth factor also shows insufficient results (Lai et al., 2010). The more promising strategy seems to be the use of tumor specific vaccines, which induce a specific cellular immune reaction by induction of tumor specific CTL.

\section{Dendritic cells in cancer therapy}

A specific cellular immune response against tumors is based on the uptake and presentation of tumor antigens on MHC molecules by professional antigen presenting cells leading to the induction of antigen specific CTL, which can then attack the tumor. Dendritic cells (DC) are the most potent antigen presenting cells and have been shown to be able to induce an efficient and specific immune response (Banchereau \& Steinman, 1998; Steinman, 1991; Whiteside \& Odoux, 2004). In comparison to other antigen presenting cells, like B cells, which induce and activate only memory $\mathrm{T}$ cells, dendritic cells can stimulate naive $\mathrm{T}$ cells (Banchereau \& Steinman, 1998; Steinman, 1991; Whiteside \& Odoux, 2004). Thus, today one of the most promising immunological therapy approaches in treatment of various types of human cancer is a specific immunotherapy with autologous dendritic cells (Engleman, 2003; Gilboa, 2007; Nestle, 2000).

According to their phenotype and functional properties dendritic cells can be classified as immature and mature type (Banchereau \& Steinman, 1998). Immature dendritic cells are able to capture and internalize particles and soluble antigens from the environment (Banchereau \& Steinman, 1998). Upon being internalized, antigens are processed and split into peptides, which are then presented on the cell surface in association with MHC molecules (Banchereau \& Steinman, 1998). In response to micro-environmental signals immature DC switch to a mature phenotype with T cell stimulatory capacity (Vieira et al., 2000; Whiteside \& Odoux, 2004). Mature dendritic cells express higher levels of major histocompatibility complex class I and class II molecules as well as co-stimulatory molecules like CD80 and CD86 (Dietz et al., 2000; Whiteside \& Odoux, 2004). During the maturation process DC lose their ability to take up and process antigens (Dietz et al., 2000; Whiteside \& Odoux, 2004). Mature dendritic cells are characterised by a distinct cytokine expression profile and their increased ability to produce Interleukin 12 (IL-12) in response to environmental signals, a cytokine known to be necessary for induction of TH1-T cell response leading to production and proliferation of CTL (Whiteside \& Odoux, 2004, Rouard et al., 2002).

Until now several methods have been published to generate dendritic cells in vitro from monocytes isolated from the peripheral blood of volunteers or cancer patients, called monocytes-derived dendritic cells (MoDC) in the presence of GM-CSF and IL-4 (Morse et al., 2002; Peters et al., 1996; Romani et al., 1996, Sallusto \& Lanzavecchia 1994, Zhou \& Tedder, 1996). Immature MoDC can be loaded either with tumor-cell-lysate, known tumor specific peptides or with specific RNA or DNA. Upon exposure to various maturation stimuli the antigen loaded immature MoDC can be matured and are able to induce a clinical antitumor response in patients with various types of tumors through induction of tumor specific CTL, which can then attack the tumor (Engleman, 2003; Gilboa, 2007; Morse et al., 2002; Nestle, 2000; Romani et al., 1996, Zhou \& Tedder, 1996). 


\subsection{Dendritic cell based immunotherapy in patients with GBM}

Although the tumor is hidden behind the blood brain barrier immune cells can be recruited into the central nervous system (Tambuyzer et al., 2009; Vauleon et al., 2010; Wilson, et al., 2010). Macrophages and dendritic cells are found in perivacscular zones, the choid plexus and the meninges (Vauleon et al., 2010). In gliomas infiltration of CD8+ as well as CD4+ T cells have been reported (Barcia et al., 2009; Mittelbronn et al, 2007). Thus, several types of immune reactions take place in primary brain tumors. In this context Ueda and coworkers have found T cells directed against two glioma antigens (IL13Ra2 and EphA2) within the peripheral blood mononuclear cells from a long surviving patient with an anaplastic astrocytoma (Ueda et al., 2007), showing that an efficient immune reaction in brain tumors is generally possible. Hoverer, the tumor itself shows variety of so-called "tumor escape mechanisms" which are able to dampen tumor antigen-specific immune responses. These include an immunosuppressive environment by secretion of immunosuppressive cytokines and factors such as transforming growth factor beta (TGF $\beta$ ) (Schneider et al., 2006) and vascular endothelial growth factor (Naumov et al., 2006), which increase the number of tumor infiltrating regulatory $\mathrm{T}$ cells and lower the number of cytotoxic killer cells and others. Moreover, the high expression of HLA-4 on gliomas, upon binding to NKG2A7B has a negative effect on $\mathrm{T}$ and NK cell activity (Wischhusen et al., 2005). Thus, in GBM the immune reactions are mostly not effective as shown by the unfavorable course of the disease and the high level of recurrences. A specific immunotherapy based on ex vivo generated antigen loaded monocyte-derived dendritic cells may overcome this inhibition leading to a re-induction of an efficient immune reaction against GBM. Such immune responses require antigen recognition. Several groups demonstrated an over-expression of several antigens including a mutated form of the Epidermal Growth Factor Receptor (EGFRvIII), GP 100 and MAGE 1 (Okada et al., 2009; Saikali et al., 2007), which could be used as targets for induction of an antigen specific immune response by priming the MoDC with peptides from these antigens. However, using the whole tumor cell lysate as well as tumor RNA as antigen source may probably reduce the risk of an immune evasion due to clonal expansion of antigen-loss tumor cell variants (Jäger et al, 1996, Vauleon et al., 2010).

Several reports have demonstrated that specific cellular immunotherapy using dendritic cells is capable of inducing a clinical antitumor response within the immunologically privileged brain, confirming that the central nervous system (CNS) is accessible to this kind of immunotherapy. Table I gives an overview on clinical studies with dendritic cell vaccines performed for glioma patients. The published data are based on phase I and II trials as well as on case reports including in total over 200 patients with GBM and over 100 patients with anaplastic astrocytomas or other malignant brain tumors (table 1). Two studies and one case report include children or young adults (Ardon et al., 2010a; Caruso et al., 2004; De Vleeschouwer et al., 2004). The dendritic cells used in these studies were ex-vivo generated from patients blood monocytes using the described standard procedure and primed with peptides, autologous tumor cell lysates or tumor-derived RNA. In two trials dendritic cells were fused with autologous tumor cells (Kikuchi et al., 2001, 2004). Dendritic cells were further matured by exposure to various maturation stimuli (Ardon et al., 2010a, 2010b; De Vleeschouwer et al.; 2008; Kikuchi et al., 2004; Okada et al., 2007; Rutkowski et al., 2004; Yamanaka et al., 2005) or were used without further maturation signals (Caruso et al., 2004; De Vleeschouwer et al., 2004; Kikuchi et al., 2001; Liau et al., 2000, 2005; Yamanaka et al., 2003; Yu et al., 2001, 2004). 


\begin{tabular}{|c|c|c|c|}
\hline Antigen source & type of trial & responses & author \\
\hline $\begin{array}{l}\text { tumor cell lysate + } \\
\text { TLR-7 ligand } \\
\text { (children) }\end{array}$ & Phase I & $\begin{array}{l}\text { median OS: } \\
12.2 \text { months }\end{array}$ & Ardon et al., 2010a \\
\hline tumor cell lysate & Phase I/II & $\begin{array}{l}\text { median OS: } \\
24 \text { months }\end{array}$ & Ardon et al., 2010b \\
\hline $\begin{array}{l}\text { tumor RNA } \\
\text { (children, young } \\
\text { adults) }\end{array}$ & $\begin{array}{l}\text { Phase I } \\
\text { (relapsed brain } \\
\text { tumors) }\end{array}$ & $1 \mathrm{PR}, 4 \mathrm{SD}$ & Caruso et al., 2004 \\
\hline $\begin{array}{l}\text { tumor cell lysate } \\
\text { (4-year old child) }\end{array}$ & $\begin{array}{l}\text { case report } \\
\text { (recurrent GBM) }\end{array}$ & CR over 2 years & De Vleeschouver et al. 2004 \\
\hline tumorc ell lysate & $\begin{array}{l}\text { Phase I/II } \\
\text { (recurrent GBM) }\end{array}$ & $\begin{array}{l}\text { median OS: } \\
9.6 \text { months }\end{array}$ & De Vleeschouver et al. 2008 \\
\hline tumor cell lysate & $\begin{array}{l}\text { case report } \\
\text { (recurrent GBM) }\end{array}$ & $\begin{array}{l}\text { median OS: } \\
11 \text { months }\end{array}$ & Khan \& Yaquin, 2006 \\
\hline fusion with tumor cells & Phase I & $1 \mathrm{MR}, 4 \mathrm{SD}, 2 \mathrm{SD}$ & Kikuchi et al., 2001 \\
\hline fusion with tumor cells & $\begin{array}{l}\text { Phase I } \\
\text { (recurrent GBM) }\end{array}$ & $1 \mathrm{SD}$ in GBM & Kikuchi et al., 2004 \\
\hline peptides & $\begin{array}{l}\text { case report } \\
\text { (recurrent GBM) }\end{array}$ & no survival benefit & Liau et al., 2000 \\
\hline tumor cell lysate & $\begin{array}{l}\text { Phase I } \\
\text { de novo vs. } \\
\text { recurrent GBM }\end{array}$ & $\begin{array}{l}\text { median OS: } \\
23.4 \text { months vs. } \\
18.3 \text { months }\end{array}$ & Liau et al., 2005 \\
\hline $\begin{array}{l}\text { tumor cell lysate or } \\
\text { irradiated tumor cells }\end{array}$ & Phase I & $\begin{array}{l}2 \mathrm{PR} \\
\text { irradiated tumor } \\
\text { cells }\end{array}$ & Okada et al., 2007 \\
\hline tumor cell lysate & $\begin{array}{l}\text { Phase I } \\
\text { (recurrent GBM) }\end{array}$ & $\begin{array}{l}\text { median OS: } \\
\text { 10,5 months } \\
\end{array}$ & Rutkowski et al., 2004 \\
\hline EGFRvIII antigen & Phase I & $\begin{array}{l}\text { median OS: } \\
22.8 \text { months }\end{array}$ & Sampson et al., 2009 \\
\hline $\begin{array}{l}\text { inactivated tumor } \\
\text { cells }\end{array}$ & Phase I & $\begin{array}{l}\text { 12-/18-months } \\
\text { survival: } 46 \% / 23 \%\end{array}$ & Walker et al., 2008 \\
\hline tumor cell lysate & $\begin{array}{l}\text { Phase I/II } \\
\text { vaccine + chemo } \\
\text { vs. vaccine alone }\end{array}$ & $\begin{array}{l}\text { 2-year-survival } \\
42 \% \text { vs. } 8 \%\end{array}$ & Wheeler et al., 2004 \\
\hline tumor cell lysate & $\begin{array}{l}\text { Phase II } \\
\text { (de novo vs. } \\
\text { recurrent GBM) } \\
\end{array}$ & $\begin{array}{l}\text { median OS: } \\
642 \text { vs. } 430 \text { days }\end{array}$ & Wheeler et al., 2008 \\
\hline tumor cell lysate & Phase I/II & OS: > 200 weeks & Yamanaka et al., 2003 \\
\hline $\begin{array}{l}\text { tumor cell lysate } \\
\text { + TLR-4 ligand }\end{array}$ & $\begin{array}{l}\text { Phase I/II } \\
\text { (recurrent GBM) }\end{array}$ & $\begin{array}{l}\text { median OS: } 480 \\
\text { (+ TLR-4 ligand) } \\
\text { vs. } 400 \text { days }\end{array}$ & Yamanaka et al., 2005 \\
\hline antigens & Phase I & $\begin{array}{l}\text { median OS: } \\
455 \text { days }\end{array}$ & Yu et al., 2001 \\
\hline
\end{tabular}

Abbreviations: OS: Overall Survival; PR: Partial Remission; CR: Complete Remission; SD: Stable Disease

Table 1. Clinical Studies for GBM treated with autologous DC 
For all used methods of MoDC generation a clinical response was described. With the exception of one trial (Yamanaka et al., 2003), where some patients receive an intracerebral injection of dendritic cells, the vaccines were administered intradermally or subcutaneously. The reported side effects were in general low besides one case with grade IV neurotoxicity (Yamanaka et al., 2005). Such reactions are probably based on an excessive inflammatory process within the brain leading to the development of severe edema. Based on our experiences, in those cases, an immune suppressive treatment with corticosteroids has to be accompanied to modulate the highly inflammatory process, which can of course counteract the efficacy of the immune response. The reported major side effects are short term flu like symptoms like fever, headaches and chill. Thus, this treatment is well tolerable without having a negative impact on the quality of life.

Clinical responses based on radiological findings, which were performed for a part of the treated patients $(\mathrm{n}=108$ patients with GBM) consisted of complete remissions $(3.7 \%)$, partial remissions $(4.6 \%)$, stable diseases $(12.9 \%)$ and mixed responses $(5.5 \%)$. In some trials a prolongation of the overall survival compared with historical data or non randomized control groups are described (Ardon et al., 2010b; De Vleeschouwer et al., 2008; Liau et al., 2005; Sampson et al., 2009; Rutkowski et al., 2004; Wheeler et al., 2008; Yamanaka et al., 2003, 2005; Yu et al., 2001, 2004). In a pilot trial published by Ardon and coworkers 8 patients with de novo diagnosed GBM received an immunotherapy with tumor cell lysate pulsed dendritic cells after surgery and radio-chemotherapy. The median overall survival was 24 months ranging from 13 to 44 months (Ardon et al., 2010b). Comparable results with a median survival of 22.8 months are reported from Sampson and coworkers using dendritic cells pulsed with the mutated EGFRvIII antigen coupled to KLH (Sampson et al., 2009). Even in patients with relapsed GBM a dendritic cell therapy is reported to be successful. De Vleeschouwer and coworkers reported a case of a 4 year old child, who received a dendritic cell therapy after surgery of recurrence. 2 years after onset of the immune therapy the child still remains in a complete remission (De Vleeschouwer et al., 2004). In a phase I/II trial performed by the same group (De Vleeschouwer et al., 2008) 56 patients were treated with dendritic cells pulsed with tumor cell lysate after surgery of recurrences. The median overall survival was 9.6 months with a 2-year survival rate of $14.8 \%$ after onset of the therapy.

Besides these very promising results the objective clinical responses are low and a lot of patients fail to respond to the therapy. One main reason for low clinical efficacy of MoDCbased anticancer therapies could be due to low IL-12 and high IL-10 production by the MoDC favoring a TH2 rather than a TH1 immune response. In fact, a lot of clinically approved maturation protocols mature MoDC insufficiently in a TH1-polarizing direction (Hildenbrandt et al., 2007, 2008; Mailliard et al., 2004; Zobywalski et al., 2007). Hildenbrandt and coworkers found that the used cytokine cocktail with TNF-a, IL-1B, IL-6 and PGE2 according to Jonuleit et al. (Jonuleit et al., 1997) induce the phenotypic characteristics of fully matured MoDC expressing high levels of CD83, MHC, costimulatory molecules and CCR7, but secrete high levels of IL-10 and only low levels of IL-12p70 suggesting a preference for a TH2-polarisation (Hildenbrandt et al., 2008). For this reason, improved maturation protocols are required. In this context the activation of Toll-like receptors (TLR) by adding TLRligands to the MoDC cultures becomes an interesting alternative to mature monocytesderived dendritic cells.

\subsubsection{Toll-like receptor agonists in maturation protocols for dendritic cells}

The expression of certain Toll-like receptors (TLR), a family yet 11 identified transmembrane receptors, expressed on dendritic cells plays a crucial role in the recognition of microbial or 
viral infections (Medzhitov, 2001). TLR mediated activation of dendritic cells is supposed to be vital for the generation of a TH1 effector response (Schnare et al., 2001). Thus, TLR ligands, which are molecular signatures of microbial or viral infections, may signal the presence of an infection (danger signal), which leads to maturation of DC with a TH1 polarization profile (Akira et al., 2001; Medzhitov, 2001). Interestingly, the TLR 3, a cell surface receptor for double-stranded RNA as well as for the synthetic analogue poly I:C, is predominantly expressed on dendritic cells (Alexopoulou et al., 2001; Muzio et al., 2000). Bone marrow derived immature dendritic cells activated by poly I:C produce large amounts of IL-12 and up-regulate MHC as well as co-stimulatory molecules on their surface (Alexopoulou et al., 2001).

Several TLR are also expressed on monocytes and immature monocytes-derived dendritic cells (Visintin et al., 2001). Moreover, it has been shown that immature MoDC have an increase in TLR 3 expression as compared to monocytes, indicating that in MoDC this TLR may play an important role (Visintin et al., 2001). At the ASCO meeting 2007 our group have show that immature MoDC from patients with GBM when activated by adding the TLR 3 ligand poly I:C switch to a mature phenotype with up-regulation of the maturation marker CD83 and of co-stimulatory molecules. After short time exposure to IFN- $\gamma$ these matured MoDC were able to produce IL-12p70 at a higher level than IL-10 which clearly favours a TH1 response (Nesselhut et al., 2007). Moreover the IL-12/IL-10 ratio seems to be correlated to clinical response. The use of poly I:C is currently tested in a phase I/II trial and recent published data show that poly I:C boosted DC are safe and have clinical anti tumor activity (Okada et al., 2010). Furthermore, the authors found a correlation between the IL-12 production level and the time to progression (Okada et al, 2010). Comparable data was seen by Yamanaka and coworkers using DC matured with a ligand to TLR 4. Patients who received TLR matured DC had longer survival than those vaccinated with immature DC (Yamanaka et al., 2005). Van Gool et al. reported an improvement of the progression free survival of glioma patients, when the skin at the injection site of the mature DC was pretreated with the TLR-7 agonist Imiquimod (van Gool et al., 2009). Concordant with findings from our group Hildebrandt et al. found that the addition of INF- $\gamma$ to TLR-agonists can improve the maturation status as well as the TH1 polarization of MoDC (Hildenbrandt et al., 2008). However, most TLR-agonists are not clinically approved and therefore are not allowed to be used in clinical trials, yet. In this context it is interesting, that Hildenbrandt et al. could show that IFN- $\gamma$ when added to the clinical-grade cytokine cocktail (Jonuleit et al., 1997) induces the production of lower levels of IL-10 and higher levels of IL-12p70, demonstrating the TH1-prolarizing capacity of this cytokine (Hildenbrandt et al., 2008).

\subsubsection{Impact of cancer induced immune suppression on the efficacy of denditic cell therapy}

During the last years several investigations show an increasing evidence of a strong association between chronic infection, inflammation and cancer development as well as tumor progression (Balkwill \& Mantovani, 2001; Coussens \& Werb, 2002). Inflammation is a physiological process occurring after tissue damage, infections caused by microbial or viral pathogen, chemical irritation or wounding (Philipp et al., 2004.) In fact, many of the same inflammatory mediators that are secreted by wounds are found in the tumor microenvironment. Immune cells infiltrate into the developing tumor site and establish an inflammatory tumor microenvironment (Balkwill \& Mantovani, 2001; Whiteside, 2008). As wound healing is self limited cancer can be described as "wounds that do not heal" (Dvorak, 
1986). Meanwhile it is well established that the tumor per se can change the immunological balance into an inflammatory microenvironment by release of certain cytokines and chemokines leading not only to the promotion of tumor growth but also to the inhibition of an efficient immune response. This may be one of the reasons for an unsuccessful immunotherapy for GBM patients based on dendritic cells (Couldwell et al., 1991, Nitta et al., 1994, Hishii et al, 1995, Weller \& Fontana, 1995). An example is the intratumoral expression of TGF- $B$, which can suppress an adaptive antigen specific immune response. Moreover, TGF- $B$ expression was shown to be a predictive factor for the clinical outcome in vaccinated patients (Liau et al., 2005).

Taken together, an efficient induction of a clinical antitumor response requires both a polarization of MoDC in a TH1 direction as well as a change of the immune suppressive tumor associated microenvironment. Beside several cytokines which promote an immune suppressive microenvironment, regulatory $\mathrm{T}$ cells (T-reg), which are required for maintaining immunological self tolerance (Sakaguchi, 2005), play an important role in the regulation of an immune response and thus may limit an antigen specific immune response in cancer (Borsellino et al. 2007; Deaglio et al. 2007; Mandapathil et a., 2009; Nizar et al, 2009).

Several subpopulations of T-reg have been described (Sakaguchi, 2005; Seddiki et al., 2006). Most commonly used is the CD4+, CD25 +high, CD127-/dim phenotype with intracellular expression of the transcription factor FoxP3 (Seddiki et al., 2006). More recently, a subpopulation of CD39+ T-reg was described (Borsellino et al. 2007; Deaglio et al., 2007). CD39 belongs to the family of ecto-nucleoside triphosphate-diphosphatehydrolase-1 and hydrolyses extracellular ATP. This leads to a pericellular accumulation of the nucleoside adenosine, which is known to play an important role in inhibiting effector functions of activated T cells (Borsellino et al. 2007, Huang et al., 1997). The authors propose that the immune suppressive activity of T-reg is partly due to this enzymatic activity of CD39 and thus may play a crucial role in inhibition of antigen specific $\mathrm{T}$ cell response. Woo et al. were the first who reported an increased percentage of T-reg cells in tumor infiltrating lymphocytes in non-small-cell-lung cancer and ovarian cancer (Woo et al., 2001). Meanwhile accumulating T-reg cells are detected in the tumor microenvironment, ascites as well as in the peripheral blood of cancer patients and have been associated with poor prognosis (Beyer \& Schultze 2010; Nizar et al. 2009, Wolf et al., 2003).

Our group have shown that subpopulations of T-reg characterized by a CD4+, CD25 +high as well as CD127-/dim or CD39+ expression profile can be detected in the peripheral blood of healthy donors, tumor free patients as well as patient with tumor load (Neßelhut et al., 2009). The percentage of T-reg was significantly higher in cancer patients, including patients with GBM, as compared to healthy donors. Moreover, patients with advanced tumors show higher levels of T-reg cells as compared to patients with no evidence of disease. Several other groups reported an increase of T-reg cells in GBM patients in peripheral blood as well as within the tumor microenvironment (Fecci et al., 2006a; Grauer et al., 2007; Hussain et al., 2006, El Andaloussi et al., 2006). Measurement of T-reg cells along with an immune therapy may be useful to discriminate between non- responding and responding patients. In fact, first analysis of our group show that rising T-reg numbers are partly associated with lack of clinical response to a dendritic cell therapy in patients with GBM. Thus, the elimination of excessive T-reg cell numbers seems to be a promising approach to improve the efficacy of a dendritic cell based immune therapy. 
Several chemotherapeutical agents have immune stimulatory and T-reg modulating effects when used at lower dosages with reduced toxic effects (Nizar et al., 2009). Beside this option there are some reagents which target T-reg directly through recognition of CD25 (Morse et al., 2008, Fecci 2006 b) or through CTLA-4 blockade (Ribas et al., 2009). Some of these approaches are tested in association with DC therapy in cancer (Chiringelli et al, 2004, Ribas et al. 2009, Morse et al., 2008) including GBM (Fecci ate al. 2006 b, Maes et al., 2009). Interestingly, in a rat glioma model low dose temozolamide could also decrease the number of T-reg cells. (Banissi et al, 2009). In this context it is noteworthy that Wheeler et al. show that GBM patients, who responded to DC therapy, also exhibited a better response to a following chemotherapy (Wheeler et al., 2004). In the study published by Ardon et al. immunotherapy based on dendritic cells started after radio-chemotherapy (Ardon et al., $2010 \mathrm{~b})$. One can suppose that the chemotherapy with temozolamide has lead to a decrease of T-reg cells and thus enhanced the immunological response causing the high 24 months median survival for the treated patients. The combination of dendritic cell therapy and adjuvant chemotherapy was also tested in malignant astrocytomas (Walker et al., 2008). The 12 - and 18-months survival rates were $46 \%$ and $23 \%$, respectively. Depletion or inhibition of T-reg may thus improve the efficacy of dendritic cell based therapy.

\subsubsection{Newcastle disease virus in treatment of GBM; a tool for improving DC therapy}

Besides dendritic cell therapy another promising approach for the treatment of malignant brain tumors is the treatment with replication-selective viruses, also called oncolytic viruses. This is based on the fact that most tumor cells are more or less unable of an effective virus defense. This approach is also known as virotherapy. The application of viruses for cancer treatment is based on reports since the beginning of the $20^{\text {th }}$ century on temporary improvement of cancer following natural viral infections or vaccinations against viral diseases. (DePace 1912). Meanwhile several replication competent viruses (mainly herpes and adenoviruses) were tested in vitro, in animal models as well as in phase I/II clinical trials for treatment of malignant brain tumors (Shah et al., 2003; Rainov \& Ren, 2003; Wollmann et al., 2005). However, the viruses have to be genetically modified in a way that makes sure that they selectively infect and replicate in tumor cells. Within the viruses tested for human anticancer treatment the Newcastle Disease Virus (NDV), an enveloped poultry virus with single strained RNA as genetic material, seems to be one of the most promising candidates. NDV is not a pathogen for humans, and is absolutely harmless causing only mild flu-like symptoms or conjunctivitis in the worst of cases (Lorence et al., 2001; Reichard et al., 1992). NDV shows a natural distinct tropism for cancer cells. Cancer cells infected with NDV can be killed directly by the virus within a short time after infection, whereas normal infected cells are not lysed by NDV.

As described earlier tumor cell lysate may be the better antigen source for priming of dendritc cells because it contains the whole antigen repertoire of the tumor. However, it has to be taken in mind that most of the antigens expressed in tumors are poor inducers of immune response and are often recognized by the immune system as self antigens (Vergati et al., 2010). Opposed to this adjuvant active specific immunization based on tumor cells modified with a low pathogenic strain of the NDV has been reported to achieve sustained immune responses in patients with advanced colonic cancer and liver metastasis (Lehner et al., 1990 Schulze et al., 2009). NDV can have lytic activity on tumor cells directly as well as 
immune stimulating properties that affect both innate and adaptive immune responses. Infection of tumor cells with live NDV results in a potent up-regulation of cell adhesion molecules on the tumor cells surface (Lehner et al. 190; Wasburn et al., 2002). Moreover, NDV infection of tumor cells leads to an improved tumor cell / $\mathrm{T}$ cell interaction and an increased T cell co-stimulatory activity (Ertel et al., 1993; Termeer et al., 2000). Expression of viral proteins on the tumor cell surface and presence of virus derived pathogen-associated molecular patterns (e.g. double-stranded RNA) result in breaking of host tolerance towards the tumor in vitro (Bai et al., 2002). The T cell stimulatory action of dendritic cells pulsed with lysates of NDV infected tumor cells as well as the antitumor cytotoxicity of macrophages and monocytes is increased (Schirrmacher et al., 2000; Washburn et al., 2003; Zeng et al., 2002). Finally, NDV induces an increased production of various cytokines, e.g. Interferon- $\alpha$ as well as chemokines, influencing the migration, the activation status and cytotoxic activity of various immune cells (Lokuta et al., 1996; Schirrmacher 2005, Schlag et al., 1992). Clinical phase I and II studies in various tumor entities have proven the safety of active specific immunization with NDV-modified tumor cells. A detailed description of the mechanisms of action of NDV modified tumor cell vaccines and results from other studies in cancer patients were reviewed by Schirrmacher (Schirrmacher, 2005).

In malignant brain tumors case reports as well as clinical phase I/II studies have shown that treatment with intravenously applied NDV as well as with vaccines utilizing NDV modified tumor cells can induce a clinical anti-tumor response in malignant brain tumors with objective clinical responses as well as with a trend towards improvement of overall survival (Csatary \& Bakacs, 1999, Csatary et al., 2004; Freeman et al., 2005; Schneider et al., 2001; Wagner et al., 2006). Recent results from our group show that a therapy with dendritic cells in combination with the NDV virotherapy may improve the clinical anti-tumor response in patients with GBM (Neßelhut et al., 2007, 2011). Patients were pre-treated with intravenously administration of NDV. Dendritic cells were primed with NDV modified tumor cells or with NDV alone in patient with tumor recurrence. When tested in vitro, NDV primed MoDC of such treated patients induce the activation of autologous CD8+ T cells with release of IFN- $\gamma$. This leads to the hypothesis that, if viral antigens are expressed on the tumor cell surface, a NDV specific dendritic cell based therapy may lead to the induction of NDV specific CD8+ T cells and thus to the induction of a specific immune response against the virus infected cancer cell (Neßelhut et al., 2011).

\section{Conclusion}

Taken together a dendritic cell therapy as well as the NDV virotherapy have shown clinical efficacy and have been proven to be safe with only minimal side-effects. Especially patients with primary resistance against temozolamide caused by the MGMT status could benefit from such alternative therapy strategies. Furthermore, new insights in the nature and biology of glioma tumor stem cells may improve an immunological concept by using tumor stem cell specific antigens as targets in dendritic cell therapy as it was recently shown (Pellegatta et al., 2006, Stupp \& Hegi, , Xu et al., 2009). An immunotherapy with dendritic cells can either be used in adjuvant, curative settings to avoid or delay tumor recurrence or in palliative settings to keep the disease stable offering the patients a chance for prolonged overall survival. Based on current results it has to be supposed that patients with minor tumor burden or no evidence of disease are the best candidates for an immunotherapy. 
The main reasons for a deficient anti-tumor immune response are most likely the immune suppressive tumor microenvironment and the up-regulation of immune suppressive cells. Thus, a combination with therapies, which can modulate the tumor microenvironment as well as lower the percentage of the immune suppressive T-reg cells should be considered as treatment prior to or in combination with dendritic cell based immune therapy. Additionally, glioma cells are considered to be poor antigen-presenting cells. In order to promote antigen-specific recognition and avidity of potential anti-tumor effector cells, the biology of antigens expressed by malignant glioma cells must be taken into consideration while designing protocols for programming autologous dendritic cells and defining the appropriate patient. For example, Prins and coworkers could recently shown that the gene expression profile of the individual glioma can identify a subgroup of patients, that may be more responsive to dendritic cell based immunotherapy (Prins et al., 2011). In this context the combination with NDV seems to be a promising tool to modify tumor cells in vitro as well as in vivo to a more immunogenic phenotype resulting in better immune recognition as well as in better immune response.

The encouraging results of phase I/II trials have to be confirmed in phase III studies with special emphasis on the maturation protocols for improvement of TH1-polarisation of dendritic cells, which so far are still a matter of controversial discussion. Moreover, the optimal antigen source, cell number of injected dendritic cells, frequency of vaccinations as well as the right time point for vaccination are still not fully defined. Future studies should also involve an immune monitoring of vaccinated patients. Immune monitoring methods can include quantification of CD8+ and CD4+ T cells generated in response to the antigen or measurement of the functional status of $\mathrm{T}$ cells analyzed by cytokine production. However, it has to be taken into account that in vitro measurement of T cell responses do not always correlate with clinical outcome (Carpentier \& Meng, 2006). Thus, the best immunological monitoring strategy is still intensively debated.

Finally, clinical trials for the evaluation of immune therapeutical approaches have to be designed in a different way as for chemotherapeutical drugs. In this context the overall survival rather than the reduction of tumor burden is probably the best primary endpoint. Based on such a study design Provenge ${ }^{\mathrm{TM}}$, an immunological treatment based on antigen presenting cells, received the FDA approval for treatment of hormone refractory prostate cancer in spring 2010.

\section{References}

Akira, S., Takeda, K. \& Kaisho, T. (2001). Toll-like receptors: critical proteins linking innate and acquired immunity. Nature Immunology, Vol. 2, No. 8, (Aug 2001), pp. 675-680

Alexopoulou, L, Czopik-Holt, A, Medzhitov, R \& Flavell, R (2001). Recognition of double stranded RNA and activation of NF-kb by Toll-like receptor 3. Nature, Vol. 413, No. 6857, (Oct 2001), pp. 732-738

Ardon, H., De Vleeschouwer, S., Van Calenbergh, F, Claes, L., Kramm, CM. et al. (2010a). Adjuvant dendritic cell-based tumour vaccination for children with malignant brain tumours. Pediatric Blood and Cancer, Vol. 54, No. 4, (April 2010), pp. 519-525

Ardon, H., Van Gool, S., Lopes IS. Maes, W., Sciot, R. et al. (2010b). Integration of autologous dendritic cell-based immunotherapy in the primary treatment for patients with newly diagnosed glioblastoma multiforme: a pilot study. Journal of Neurooncology, Vol. 99, No. 2, (Sep 2010), pp. 261-272 
Bai, L., Koopmann, J., Fiola, C., Fournier, P. \& Schirrmacher, V. (2002). Dendritic cells pulsed with viral oncolysates potently stimulate autologous $\mathrm{T}$ cells from cancer patients. International Journal of Oncology, Vol. 21, No. 4, (Oct 2002), pp. 685-694

Balkwill, F. \& Mantovani, A. (2001). Inflammation and cancer: back to Virchow? Lancet, Vol. 357, No. 9255, (Feb 2001), pp. 539-545

Banchereau, J. \& Steinman, RM. (1998). Dendritic cells and the control of immunity. Nature, Vol. 392, No. 6673, (Mar 1998), pp. 245-252

Banissi C., Chiringhelli F., Chen, L. \& Carpentier, AF. (2009). Treg depletion with a low-dose metronomic temozolomide regimen in a rat glioma model. Cancer Immunology Immunotherapy, Vol. 58, No. 10, (Oct 2009), pp. 1627-1634

Barcia, C., Gomez, A., Gallego-Sanchez, JM., Perez-Vallés, A., Castro, MG. et al. (2009). Infiltrating CTLs in human glioblastoma establish immunological synapses with tumorigenic cells. American Journal of Pathology, Vol. 175, No. 2, (Aug 2009), pp. 786789

Beyer, M. \& Schultze, JL. (2006). Regulatory T cells in cancer. Blood, Vol. 108, No. 3, (Aug 2006), pp. 804-811

Borsellino, G., Kleinewietfeld, M., Di Mitri, D., Sternjak, A,, Diamantini, A. et al. (2007). Expression of ectonucleotidase CD39 by Foxp3+ Treg cells: hydrolysis of extracellular ATP and immune suppression. Blood, Vol. 110, N0. 4, (Aug 2007), pp. $1225-1232$

Buckner, JC. (2003). Factors influencing survival in high-grade gliomas. Seminars in Oncology, Vol. 30, Suppl. 19, pp. 10-14

Carpentier, AF. \& Meng, Y. (2006). Recent advances in immunotherapy for human glioma. Current Opinion Oncology, Vol. 18, No. 6, (Nov 2006), pp. 631-636

Caruso, DA., Orme, LM., Neale, AM., Radcliff, FJ., Amor, GM. et al. (2004). Results of a phase 1 study utilizing monocyte-derived dendritic cells pulsed with tumor RNA in children and young adults with brain cancer. Journal of Neurooncology, Vol. 6, No. 3, (Jul 2004), pp. 236-246

Chang, CH., Horton, J, Schoenfeld, D., Salazer, O., Perez-Tamayo, R. et al. (1983). Comparison of postoperative radiotherapy and combined postoperative radiotherapy and chemotherapy in the multidisciplinary management of malignant gliomas: a joint Radiaton Therapy Oncology Group and Eastern Cooperative Oncology Group study. Cancer, Vol. 52, pp. 997-1007

Couldwell, WT., Dore-Duffy, P., Apuzzo, MLJ. \& Antel, JP. (1991). Malignant glioma modulation of immune function: relative contribution of different soluble factors. Journal of Neuroimmunology, Vol. 33, No. 2, (Aug 1991), pp. 89-96

Coussens, LM. \& Werb, Z. (2002). Inflammation and cancer. Nature, Vol. 420, No. 6917), (Dec 2002), pp. 860-867

Csatary, LK. \& Bakacs, T. (1999). Newcastle disease virus vaccine (MTH-68/H) in a patient with high-grade glioblastoma. Jama, Vol. 281, No. 17, (May 1999), pp. 1588-1589

Csatary, LK., Gosztonyi, G., Szeberenyi, J., Fabian, Z., Liszka, V. et al. (2004). MTH-68/H oncolytic viral treatment in human high-grade gliomas. Journal of Neurooncology, Vol. 67, No. 1-2, (Mar-Apr), pp. 83-93

Curran, WJ. Jr., Scott, CB., Horton, J., Nelson, JS., Weinstein, AS. et al. (1993). Recursive portioning analysis of prognostic factors in three Radiation Therapy Oncology 
Group malignant glioma trials. Journal of National Cancer Institute, Vol. 85, No. 9, (May 1993), pp. 704-710

Deaglio, S., Dwyer, KM., Gao,. W, Friedman, D., Usheva, A., et al. (2007). Adenosine generation catalyzed by CD39 and CD73 expressed on regulatory T cells mediates immune suppression. Journal of Experimental Medicine, Vol. 204, No. 6, (Jun 2007), pp. $1257-65$

De Angelis, LM. (2001). Brain tumors. New England Journal of Medicine, Vol., 344, No. 2, (Jan 2001), pp. 114-123

De Pace, NG. (1912). Sulla scomparsa di un enorme cancro vegetante del callo dell 'utero senza cura chirurgica. Ginecologia, Vol. 9, (1912), pp. 82-88

De Vleeschouwer, S., Van Calenbergh, F., Demaerel, P., Flamen, P., Rutkowski, S. et al. (2004). Transient local response and persistent tumor control in a child with recurrent malignant glioma: treatment with combination therapy including dendritic cell therapy: case report. Journal of Neurosurgery, Vol. 100, No. 5, (May 2004), pp. 492-497

De Vleeschouwer, S., Fieuws, S, Rutkowski, S. Van Calenbergh, F., Van Loon, J. et al. (2008). Postoperative adjuvant dendritic cell-based immunotherapy in patients with relapsed glioblastoma multiforme. Clinical Cancer Research, Vol. 14, No. 10, (May 2008), pp. 3098-3104

Dvorak, HF. (1986). Tumors: wounds that do not heal. Similarities between tumor stroma generation and wound healing. New England Journal of Medicine, Vol. 315, No. 26, (Dec 1986), pp. 1650-1659

Dietz, AB., Bulur, PA., Knutson, GJ., Matasic, R. \& Vuk-Pavlovic, S. (2000). Maturation of human monocyte-derived dendritic cells studied by microarray hybridization. Biochem Biophys Res Commun, Vol. 275, No. 3, (Sep 2000), pp. 731-738

El Andaloussi, A \& Lesniak, MS. (2006). An increase in CD4+ CD25+FOXP3+ regulatory T cells in tumor-infiltrating lymphocytes of human glioblastoma multiforme. Neurooncology, Vol. 8, No. 3, (Jul 2006), pp. 234-243

Engleman, EG. (2003). Dendritic cell-based cancer immunotherapy. Seminars in Oncology, Vol. 30, No. 3, (Jun 2003), pp. 23-29

Ertel, C., Millar, NS., Emmerson, PT., Schirrmacher, V. \& von Hoegen, P. (1993). Viral hemaglutinin augments peptide-specific cytotoxic T cell responses. European Journal of Immunology, Vol. 23, No. 10, (Oct 1993), pp. 2592-2596

Fecci, PE., Mitchell, DA., Whitesides JF., Xie, W., Friedmann, AH. et al. (2006). Increased regulatory $\mathrm{T}$-cell fraction amidst a diminished CD4 compartment explains cellular immune defects in patients with malignant glioma. Cancer Research, Vol. 66, No. 6, (Mar 2006), pp. 3294-3302

Fecci, PE., Sweeney, AE., Grossi, PM., Nair, SK., Learn, CA. et al. (2006). Systemic anti-CD25 monoclonal antibody administration safely enhances immunity in murine glioma without eliminating regulatory T cells. Clinical Cancer Research, Vol. 12, No. 14, (Jul 2006), pp. 4294-4305

Freeman, AI., Zackay-Rones, Z., Gomori, JM., Linetsky, E., Rasooly, L. et al. (2005). Phase I/II trial of intravenous NDV-HUJ oncolytic virus in recurrent glioblastoma multiforme. Molecular Therapy, Vol. 13, No. 1, (Jan 2005), pp. 221-228

Ghiringhelli, F., Larmonier, N., Schmitt, E., Parcellier, A., Cathelin, D. et al. (2004). $\mathrm{CD} 4+\mathrm{CD} 25+$ regulatory $\mathrm{T}$ cells suppress tumor immunity but are sensitive to 
cyclophosphamide which allows immunotherapy of established tumors to be curative. European Journal of Immunology, Vol. 34, No. 2, (Feb 2004), pp. 336-344

Gilboa, E. (2007). DC-based cancer vaccines. Journal of Clinical Investigation, Vol. 117, No. 5, (May 2007), pp. 1195-1203

Grauer, OM., Nierkens, S., Bennink, E., Toonen, LW., Boon, L. et al. (2007). CD4+FoxP3+ regulatory $\mathrm{T}$ cells gradually accumulate in gliomas during tumor growth and efficiently suppress antiglioma immune responses in vivo. International Journal of Cancer, Vol. 121, No. 1, (Jul 2007), pp. 95-105

Green, SB., Byar, DP., Walker, MD., Pistenmaa, DA., Alexander, E.Jr. et al. (1983). Comparisons of carmustine, procarbazine, and high-dose methylprednisolone as additions to surgery and radiotherapy for the treatment of malignant glioma. Cancer Treat Rep, Vol. 67, No.2, (Feb 1983), pp. 121-132

Hildenbrand, B., Sauer, B., Kalis, O., Stoll, C., Freudenberg, MA. et al. (2007). Immunotherapy of patients with hormone-refractory prostate carcinoma pretreated with interferon-gamma and vaccinated with autologous PSA-peptide loaded dendritic cells - A pilot study. Prostate, Vol. 67, No. 2, (Apr 2007), pp. 500508

Hildenbrand, B., Lorenzen, D., Sauer, B., Hertkorn, C., Freudenberg MA. et al. (2008). IFN-g enhances TH1 polarization of monocyte-derived dendritic cells matured with clinical-grade cytokines using serum-free conditions. Anticancer Research, Vol. 28, No. 3A, (May-Jun 2008), pp. 1467-1476

Hishii, M., Nitta, T., Ishida, H., Ebato, M., Kurosu,. A. et al. (1995). Human glioma derived interleukin-10 inhibits antitumor immune responses in vitro. Neurosurgery, Vol. 37, No. 6, (Dec 1995), pp. 1160-1166

Huang, S., Apasov, S., Koshuba, M. \& Sitkowski, M. (1997). Role of A2a extracellular adenosine receptor-mediated signaling in adenosine-mediated inhibition of T-cell activation and expansion. Blood, Vol. 90, No. 4, (Aug 1997), pp. 1600-1610

Hussain, SF., Yang, D., Suki, D., Grimm, E. \& Heimberger, AB. (2006). Innate immune functions of microglia isolated from human glioma patients. Journal of Translational Medicine, Vol. 4, Article ID, (Jul 2006), pp 15

Jäger, E., Ringhoffer, M., Karbach, J., Arand, M., Oesch, F. \& Knuth, A. (1996). Inverse relationship of melanocyte differentiation antigen expression in melanoma tissues and CD8+ cytotoxic-T-cell responses: evidence of immune selection of antigen-loss variants in vivo. International Journal of Cancer, Vol. 66, No. 4, (May 1996), pp. 470476

Janeway, CA., Shlomchik, MJ., Travers, P. \& Walport, M. (2004). Using the immune response to attack tumors, In: Immunobiology $6^{\text {th }}$ edn., Janeway CA, Shlomchik MJ, Travers P, Walport J (eds), pp 630-642, Garland Science, New York,

Jonuleit, H., Kuhn U, Muller G, Steinbrink, K., Paragnik L. et al. (1997). Pro-inflammatory cytokines and prostaglandins induce maturation of potent immunostimulatory dendritic cells under fetal calf serum- free conditions. European Journal of Immunology, Vol. 27, No. 12, (Dec 1997), pp. 3135-3142

Kikuchi, T., Akasaki, Y., Irie, M., Homma, S., Abe, T. \& Ohno,T. (2001). Results of a phase I clinical trial of vaccination of glioma patients with fusions of dendritic and glioma cells. Cancer Immunology Immunotherapy, Vol. 50, No. 7, (Sep 2001), pp. 337-344 
Kikuchi, T., Akasaki, Y., Abe, T., Fukuda, T., Saotome, H. et al. (2004). Vaccination of glioma patients with fusions of dendritic and glioma cells and recombinant human interleukin 12. Journal of Immunotherapy, Vol. 27, No. 6, (Nov-Dec 2004), pp. 452-459

Khan, JA. \& Yaquin, S. (2006). Dendritic cell therapy with improved outcome in glioma multiforme-a case report. J Zhejiang Univ Science B, Vol. 7; No. 2, (Feb 2006), pp. 114-117

Lai, A., Tran, A., Nghiemphu, PL., Pope, WB., Solis, OE. et al. (2010). Phase II study of bevacizumab plus temozolomide during and after radiation therapy for patients with newly diagnosed glioblastoma multiforme. Journal of Clinical Oncology, Vol. 29, No. 2, (Jan 2010), pp. 142-148

Lehner, B., Schlag, P., Liebrich, W. \& Schirrmacher, V. (1990). Postoperative active specific immunization in curatively resected colorectal cancer patients with a virusmodified autologous tumor cell vaccine. Cancer Immunology Immunotherapy, Vol. 32, No. 3, pp. 173-178

Liau, LM., Black, KL., Martin NA., Sykes, SN., Bronstein JM. et al. (2000). Treatment of a patient by vaccination with autologous dendritic cells pulsed with allogeneic major histocompatibility complex class I matched tumor peptides. Case report. Neurosurgical Focus, Vol. 9, No. 6, (Dec 2000), p. e8

Liau, LM., Prins, RM., Kiertscher, SM., Odesa, SK., Kremen, TJ. et al. (2005). Dendritic cell vaccination in glioblastoma patients induces systemic and intracranial T-cell responses modulated by the local central nervous system tumor microenvironment. Clinical Cancer Research, Vol. 11, No. 15, (Aug 2005), pp. 5515-5525

Liu, G., Yuan, X., Zeng, Z., Tunici, P., Ng, H. et al. (2006). Analysis of gene expression and chemoresistance of CD133+ cancer stem cells in glioblastoma. Mol Cancer, Vol. 5, (Dec 2006), pp. 67

Lokuta, MA., Maher, J., Noe, KH., Pitha, PM., Shin, ML. \& Shin, HS. (1996). Mechanisms of murine RANTES chemokine gene induction by Newcastle disease virus. J Biol Chem, Vol. 271, No. 23, (Jan 1996), pp. 13731-13738

Lorence, RM., Roberts, MS., Groene, WS. \& Rabin, H. (2001). Replication-competent, oncolytic Newcastle disease virus for cancer therapy. In: Replication competent viruses for cancer therapy, Vol. 22, Hernaiz-Driever, Rabkin (eds), pp. 160-182, Karger, Basel

Maes, W., Rosas, G., Verbinnen, B. Boon, L., De Vleeschouwer, S., Ceuppens, JL. \& Van Gool, SW. (2009). DC vaccination with anti-CD25 treatment leads to long-term immunity against experimental glioma. Neurooncology, Vol. 11, No. 5, (Oct 2009), pp. 529-542

Mandapathil, M., Hilldorfer, B., Szczepanski, MJ., Czystowska, M., Szajnik, M. et al. (2009). Generation and accumulation of immunosuppressive adenosine by human CD4+CD25highFOXP3+ regulatory T cells. J Biol Chem, Vol. 285, No. 10, (Mar 2009), pp. 7176-7186

Mailliard, RB., Wankowicz-Kalinska, A., Cai, Q., Wesa, A., Hilkens, CM. et al. (2004). AType-1 polarized dendritic cells: A novel immunization tool with optimized CTLinducing activity. Cancer Research, Vol. 64, No. 17, (Sep 2004), pp. 934-5937

Medzhitov, R. (2001). Toll-like receptors and innate immunity. Nat Rev Immunol, Vol. 1, No. 2(Nov 2001), pp. 135-45 
Mittelbronn, M. Simon, P., Löffler, C., Capper, D., Bunz, B. et al. (2007). Elevated HLAE levels in human glioblastomas but not in grade I to III astrocytomas correlate with infiltrating CD8+ cells. Journal of Neuroimmunology, Vol. 189, No. 1-2, (Sep 2007), pp. 50-58

Morse, MA., Mosca, P., Clay, TM. \& Lyerly, HK. (2002). Dendritic cell maturation in active immunotherapy strategies. Expert Opin Biol Ther, Vol. 2, No. 1, (Jan 2002), pp. 35-43

Morse, MA., Hobeika, AC., Osada, T., Serra, D., Niedzwiecki, D. et al. (2008). Depletion of human regulatory $\mathrm{T}$ cells specifically enhances antigen-specific immune responses to cancer vaccines. Blood, Vol. 112, No. 3, (Aug 2008), pp. 610-618

Muzio M., Bosisio, D., Polentarutti, N., D’amico, G., Stoppacciaro, A. at al. (2000). Differential expression and regulation of Toll-like receptors (TLR) in human leukocytes: selective expression of TLR3 in dendritic cells. Journal of Immunology, Vol. 164, No. 1, (Jun 2000), pp. 5998-6004

Naumov, GN., Bender, E., Zurakowski, D., Kang, SY., Sampson, D. et al. (2006). A model of human tumor dormancy: an angiogenic switch from the angiogenic phenotype. Journal National Cancer Institute, Vol. 98, No.5, (Mar 2006), pp. 316-325

Neßelhut, J., Neßelhut, T., Chang, R., Marx, D., Brockmann, W. et al. (2007). Dendritic cell therapy in glioblastoma multiforme. Journal of Clinical Oncology 25 (18S) suppl: abstract 3065, Chicago, May-Jun 2007

Neßelhut, J., Lorenzen, D., Marx, D., Chang, RY., Matthes, C. et al. (2009). Cellular immune suppression in cancer patients and its implication for dendritic cell therapy. Journal of Clinical Oncology 27 (15s) suppl: abstract 3028, Orlando, May-Jun 2009

Neßelhut, J., Marx, D., Lorenzen, D., Cillien, N., Goebel, W. et al. (2011). Improvement of dendritic cell therapy in glioblastoma multiforme WHO IV by Newcastle disease virus. Abstract 2508, Chicago, June 2011 (in progress)

Nestle, FQ. (2000). Dendritic cell vaccination for cancer therapy. Oncogene, Vol. 19, No. 56, (Dec 2000), pp. 6673-6679

Newlands, ES., Stevens, MFG., Wedge, SR., Wheelhouse, RT. \& Brock, C. (1997). Temozolomide: a review of its discovery, chemical properties, pre-clinical development and clinical trials. Cancer Treat Rev, Vol. 23, No. 1, (Jan 1997), pp. 35-61

Nitta, T., Hishii, M., Sato, K. \& Okumura, K. (1994). Selective expression of interleukin-10 gene within glioblastoma multiforme. Brain Research, Vol. 649, No. 1-2, (Jun 1994), pp. 122-128

Nizar S., Copier J., Meyer, B., Bodman-Smith, M., Galustian C. et al. (2009). T-regulatory cell modulation: the future of cancer immunotherapy? British Journal of Cancer, Vol. 100, No. 11, (Jun 2009), pp. 1697-1703

Okada, H., Lieberman, FS., Walter, KA., Lunsford, LD., Kondziolka, DS. et al. (2007). Autologous glioma cell vaccine admixed with interleukin-4 gene transfected fibroblasts in the treatment of patients with malignant gliomas. Journal of Translational Medicine, Vol. 19, No. 5, (Dec 2007), pp. 67

Okada, H., Kohanbash, G., Zhu, X., Kastenhuber, ER., Hoji, A. et al. (2009). Immunotherapeutic approaches for glioma. Critical Reviews in Immunology, Vol. 29, No. 1, pp. 1-42

Okada H., Kalinski P., Ueda R., Hoji, A., Kohanbah G. et al. (2011). Induction of CD8+ T-cell responses against novel glioma-associated antigen peptides and clinical activity by vaccinations with (alpha)-type 1 polarized dendritic cells and polyinosinic- 
polycytidylic acid stabilized by lysine and carboxymethylcellulose in patients with recurrent malignant glioma. Journal of Clinical Oncology, Vol. 29, No. 3, (Jan 2011), pp. 330-336

Pellegatta, S., Poliani, PL., Corno, D., Menghi, F., Ghielmetti, F. et al. (2006). Neurospheres enriched in cancer stem-like cells are highly effective in eliciting a dendritic cellmediated immune response against malignant gliomas. Cancer Research, Vol. 66, No. 21, (Nov 2006), pp. 10247-10252

Peters. JH., Gieseler, R., Thiele, B. \& Steinbach, F. (1996). Dendritic cells: from ontogenetic orphans to myelomonocytic descendants. Immunology Today, Vol. 17, No. 6, (Jun 1996), pp. 273

Philip, M., Rowley, DA. \& Schreiber, H. (2004). Inflammation as a tumor promoter in cancer induction. Semin Cancer Biol, Vol. 14, No. 6, (Dec 2004), pp. 433-439

Prins, RM., Soto, H., Konkankit, V., Odesa, SK., Eskin, A. et al. (2011). Gene expression profile correlates with $\mathrm{T}$-cell infiltration and relative survival in glioblastoma patients vaccinated with dendritic cell immunotherapy. Clinical Cancer Research, Vol. 17, No. 6, (Mar 2011), pp. 1603-1615

Rainov, NG. \& Ren, H. (2003). Oncolytic viruses for treatment of malignant brain tumors. Acta Neurochir Suppl. 88, pp. 113-123

Reichard, KW., Lorence, RM., Cascino, CJ., Peeples, ME., Walter, RJ. et al. (1992). Newcastle disease virus selectively kills human tumor cells. J Surg Res, Vol. 52, No. 5, (May 1992), pp. 448-453

Ribas, A. Comin-Anduix, B., Chmielowski, B., Jalil, J., de la Rocha, P. et al. (2009). Dendritic cell vaccination combined with CTLA4 blockade in patients with metastatic melanoma. Clinical Cancer Research, Vol. 15, No. 19, (Oct 2009), pp. 6267-6276

Romani, N., Reider, D. Heuer, M. et al. (1996). Generation of mature dendritic cells from human blood. An improved method with special regard to clinical applicability. Journal of Immunology Methods, Vol. 196, No. 2, (Sep 1996), pp. 1137-1151

Rouard, H., Marquet, J., Léon, A., Maison, P., Haioun, C. et al. (2002). IL-12 secreting dendritic cells are required for optimum activation of human secondary lymphoid tissue T cells. Journal of Immunotherapy, Vol. 25, No. 4, (Jul-Aug 2002), pp. 324-333

Rutkowski, S., De Vleeschouwer, S., Kaempgen, E., Wolff, JE., Kühl, J. et al. (2004). Surgery and adjuvant dendritic cell-based tumour vaccination for patients with relapsed malignant glioma, a feasibility study. British Journal of Cancer, Vol. 91, No. 9, (Nov 2004), pp. 1656-1662

Sakaguchi, S. (2005). Naturally arising Foxp3-expressing CD25+CD4+ regulatory T cells in immunological tolerance to self and non-self. Nature Immunology, Vol. 6, No. 4, (Apr 2005), pp. 345-352

Saikali, S., Avril, T., Collet, B., Hamlat, A., Bansard, JY. et al. (2007). Expression of nine tumour antigens in a series of human glioblastoma multiforme: interest of EGFRvIII, IL-13Ra2, gp100 and TRP-2 for immunotherapy. Journal of Neurooncology, Vol. 81, No. 2, (Jan 2007), pp. 139-148

Sallusto, F. \& Lanzavecchia, A. (1994). Efficient presentation of soluble antigen by cultured human dendritic cells is maintained by granulocyte/macrophage colonystimulating factor plus interleukin 4 and downregulated by tumor necrosis factor alpha. Journal of Experimental Medicine, Vol. 179, No. 4, (Apr 1994), pp. 1109-1118 
Sampson, JH., Archer, GE., Mitchell, DA., Heimberger, AB., Herndon, JE. 2nd et al. (2009). An epidermal growth factor receptor variant III-targeted vaccine is safe and immunogenic in patients with glioblastoma multiforme. Molecular Cancer Therapeutics, Vol. 8, No. 10, (Oct 2009), pp. 2773-2779

Schirrmacher, V., Bai, L., Umansky, V., Yu, L., Xing, Y, \& Qian, Z. (2000). Newcastle disease virus activates macrophages for anti-tumor activity. International Journal of Oncology, Vol. 16, pp. 363-373

Schirrmacher, V. (2005). Clinical trials of antitumor vaccination with an autologous tumor cell vaccine modified by virus infection: improvement of patient survival based on improved antitumor immune memory. Cancer Immunology Immunotherapy, Vol. 54, No. 6, Jun 2005), pp. 587-598

Schlag, P., Manasterski, M., Gerneth, T., Hohenberger, P., Dueck, M. et al. (1992). Active specific immunotherapy with Newcastle-disease-virus-modified autologous tumor cells following resection of liver metastases in colorectal cancer. First evaluation of clinical response of a phase II-trial. Cancer Immunology Immunotherapy, Vol. 35, No. 5, pp. 325-330

Schnare, M., Barton, GM., Holt, AC., Takeda, K., Akira, S. et al. (2001). Toll-like receptors control activation of adaptive immune responses. Nature Immunology, Vol. 2, NO. 10, (Oct 2001), pp. 947-950

Schneider, T., Sailer, M., Ansorge, S., Firsching, R. \& Reinhold, D. (2006). Increased concentrations of transforming growth factor beta1 and beta2 in the plasma of patients with glioblastoma. Journal of Neurooncology, Vol. 79, No. 1, (Aug 2001), pp. 61-65

Schneider, T., Gerhards, R., Kirches, E. \& Firsching, R. (2001). Preliminary results of active specific immunization with modified tumor cell vaccine in glioblastoma multiforme. Journal of Neuooncology, Vol. 53, No. 1, (May 2001), pp. 39-46

Schulze, T., Kemmer, W., Weitz, J., Wernecke, KD., Schirrmacher., V. et al. (2009) Efficiency of adjuvant active specific immunization with Newcastle disease virus modified tumor cells in colorectal cancer patients following resection of liver metastases: results of a prospective randomized trial. Cancer Immunology Immunotherapy, Vol. 58, No. 1, (Jan 2009), pp.61-69

Seddiki, N., Santner-Nanan, B., Martinson, J., Zaunders, J., Sasson, S. et al. (2006). Expression of interleukin (IL)-2 and IL-7 receptors discriminates between human regulatory and activated T cells. Journal of Experimental Medicine, Vol. 203, No. 7, (Jul 2006), pp. 1693-1700

Shah, AC., Benos, D., Gillepsie, GY. \& Markert, JM. (2003). Oncolytic viruses: clinical applications as vectors for the treatment of malignant gliomas. Journal of Neurooncology, Vol. 65, No. 3, (Dec 2003), pp. 2023-2026

Singh, SK., Clarke, ID., Terasaki, M., Bonn, VE. \& Hawkins, C. (2003). Identification of a cancer stem cell in human brain tumors. Cancer Research, Vol. 63, No. 18, (Sep 2003), pp. 5821-5828

Steinman, RM. (1991). The dendritic cell system and its role in immunogenicity. Annual Review of Immunology, Vol. 9, pp. 271-296

Stewart, LA. (2002). Chemotherapy in adult high-grade glioma: a systematic review and metaanalysis of individual patient data from 12 randomised trials. Lancet, Vol. 359, No. 9311, (Mar 2002), pp. 1011-1018 
Stupp, R., Gander, M., Leyvraz, S. \& Newlands, E. (2001). Current and future developments in the use of temozolomide for the treatment of brain tumours. Lancet Oncology, Vol. 2, No. 9, (Sep 2001), pp. 552-560

Stupp, R., Mason, WP., van den Bent, MJ., Weller, M., Fisher, B., et al. (2005). Radiotherapy plus concomitant and adjuvant temozolomide for glioblastoma. New England Journal of Medicine, Vol. 352, No. 10, (Mar 2005), pp. 987-996

Stupp, R. \& Hegi, ME. (2007). Targeting brain-tumor stem cells. Nature Biotechnology, Vol. 25, No. 2, (Feb 2007), pp. 193-194

Tang, J., Flomenberg, P., Harshyne, L., Kenyon, L. \& Andrews, DW. (2005). Glioblastoma patients exhibit circulating tumor-specific CD8+ T cells. Clinical Cancer Research, Vol. 11, No. 14, (Jul 2005), pp. 5292-5299

Tambuyzer, BR., Ponsaerts, P. \& Nouwen, JE. (2009). Microglia: gatekeepers of central nervous system immunology. Journal of Leukocyte Biology, Vol. 85, No. 3, (Mar 2009), pp. 352-370,

Termeer, CC., Schirrmacher, V., Brocker, BB. \& Becker, JC. (2000). Newcastle disease virus infection induces B7-1/B7-2-independent T-cell costimulatory activity in human melanoma cells. Cancer Gene Therapy, Vol. 7, No.2, (Feb 2000), pp. 316-323

Ueda, R., Low, KL., Zhu, X., Fujita, M., Sasaki, K., et al. (2007). Spontaneous immune responses against glioma-associated antigens in a long term survivor with malignant glioma. Journal of Translational Medicine, Vol. 19, No. 5, (Dec 2007), pp. 68

Ueda, R., Fujita, M., Zhu, X., Sasaki, K., Kastenhuber, ER. et al. (2009). Systemic inhibition of transforming growth factor- $\beta$ in glioma-bearing mice improves the therapeutic efficacy of glioma-associated antigen peptide vaccines. Clinical Cancer Research, Vol. 15, No. 21, (Nov 2009), pp. 6551-6559

Van Gool, S., Maes, W., Ardon, H., Verschuere, T., Van Cauter, S. \& De Vleeschouwer, S. (2009). Dendritic cell therapy of high-grade gliomas. Brain Pathology, Vol. 19, No. 4, (Oct 2009), pp. 694-712

Vauleon, E., Avril, T, Collet, B., Mosser, J. \& Quillien, V. (2010). Overview of cellular immunotherapy for patients with glioblastoma. Clinical and Development Immunology, (Oct 2010), pii: 689171.

Vergati, M., Intrivici, C., Huen, NY., Schlom, J. \& Tsang KY. (2010). Strategies for cancer vaccine development. Journal of Biomedical Biotechnology, (Jul 2010), pii: 596432

Vieira, PL., de Jong, EC., Wierenga, EA., Kapsenberg, ML. \& Kalinski, P. (2000). Development of Th1-inducing capacity in myeloid dendritic cells requires environmental instruction. Journal of Immunology, Vol. 164, No. 9, (May 2000), pp. 4507-4512

Visintin, A., Mazzoni, A., Spitzer, JH., Wyllie, DH., Dower, SK. \& Segal, DM. (2001). Regulation of Toll-like receptors in human monocytes and dendritic cells. Journal of Immunology, Vol. 166, No. 1, (Jan 2001), pp. 249-255

Wagner, S., Csatary, CM., Gosztonyi, G., Koch, HC., Hartmann, C. et al. (2006). Combined treatment of pediatric high-grade glioma with the oncolytic viral strain MTH-68/H and oral valproic acid. APMIS, Vol. 114, No. 10, (Oct 2006), pp. 731-743

Walker, G., Laherty, R., Tomlinson, FH., Chuah, T \& Schmidt, C. (2008). Results of a phase I dendritic cell vaccine trial for malignant astrocytoma: potential interaction with adjuvant chemotherapy. Journal of Clinical Neuroscience, Vol. 15, No.2, (Feb 2008), pp. 114-121 
Washburn, B. \& Schirrmacher, V. (2002). Human tumor cell infection by Newcastle disease virus leads to upregulation of HLA and cell adhesion molecules and to induction of interferons, chemokines and finally apoptosis. International Journal of Oncology, Vol. 21, No. 1, (Jul 2002), pp. 85-93

Washburn, B., Weigand MA., Grosse-Wilde, A., Janke, M., Stahl, H. et al. (2003). TNF-related apoptosis-inducing ligand mediates tumoricidal activity of human monocytes stimulated by Newcastle disease virus. Journal of Immunology, Vol. 170, No. 4, (Feb 2003), pp. 1814-1821

Weller, M. \& Fontana, A. (1995). The failure of current immunotherapy for malignant glioma. Tumor-derived TGF- $\beta$, T-cell apoptosis, and the immune privilege of the brain. Brain Research Reviews, Vol. 21, No. 2, (Sep 1995), pp. 128-151

Wheeler, CJ., Das, A., Liu, G., Yu, JS. \& Black, KL: (2004). Clinical responsiveness of glioblastoma multiforme to chemotherapy after vaccination. Clinical Cancer Research, Vol. 10, No. 16, (Aug 2004), pp. 5316-5326

Wheeler, CJ., Black, KL., Liu, G., Mazer, M., Zhang, X. et al. (2008). Vaccination elicits correlated immune and clinical responses in glioblastoma multiforme patients. Cancer Research, Vol. 68, No. 14, (Jul 2008), pp. 5955-5964

Whiteside, TL. \& Odoux, C. (2004). Dendritic cellbiology and cancer therapy. Cancer Immunology Immunotherapy, Vol. 53, No. 3, (Mar 2004), pp. 240-248

Whiteside, TL. (2008). The tumor microenvironment and its role in promoting tumor growth. Oncogene, Vol. 27, No. 45, (Oct 2008), pp. 5904-5912

Wilson, EH., Weninger, W. \& Hunter, CA. (2010). Trafficking of immune cells in the central nervous system. Journal of Clinical Investigation, Vol. 120, No. 5, (May 2010), pp. 1368-1379

Wischhusen, J., Friese, MA., Mittelbronn, M., Meyermann, R. \& Weller, M. (2005). HLA-E protects glioma cells from NKG2D-mediated immune responses in vitro: implications for immune escape in vivo. J Neuropathol Exp Neurol, Vol. 64, No. 6, (Jun 2005), pp. 523-528

Wolf, AM., Wolf, D., Steurer, M., Gastl, G., Gunsilius, E. \& Grubeck-Loebenstein, B. (2003). Increase of regulatory $\mathrm{T}$ cells in the peripheral blood of cancer patients. Clinical Cancer Research, Vol. 9, No. 2, (Feb 2003), pp. 606-612

Wollmann, G., Tattersal, P. \& van den Pol, AN. (2005). Targeting human glioblastoma cells: comparison of nine viruses with oncolytic potential. Journal of Virology, Vol. 79, No. 10, (May 2005), pp. 6005-6022

Woo EY., Chu, CS., Goletz, TJ., Schlienger, K., Yeh, H. et al. (2001). Regulatory CD4 (+) CD25 $(+) \mathrm{T}$ cells in tumors from patients with early-stage non-small cell lung cancer and late-stage ovarian cancer. Cancer Research, Vol. 61, No. 12, (Jun 2001), pp. 4766-4772

Xu, Q., Liu G., Yuan, X., Xu, M., Wang, H. et al. (2009). Antigen-specific T-cell response from dendritic cell vaccination using cancer stem-like cell-associated antigens. Stem Cells, Vol. 27, No. 8, (Aug 2009), pp. 1374-1740

Yamanaka, R., Abe T, Yajima, N., Tsuchiya, N., Homma, J. et al. (2003). Vaccination of recurrent glioma patients with tumour lysate-pulsed dendritic cells elicits immune responses: results of a clinical phase I/II trial. British Journal of Cancer, Vol. 89, No. 7, (Oct 2003), pp. 1172-1179

Yamanaka, R., Homma, J., Yajima, N., Tsuchiya, N., Sano, M. et al. (2005). Clinical evaluation of dendritic cell vaccination for patients with recurrent glioma: results of 
a clinical phase I/II trial. Clinical Cancer Research, Vol. 11, No. 11, (Jun 2005), pp. 4160-4167

Yu, JS., Wheeler, CJ., Zeltzer, PM., Ying, H., Finger, DN. et al. (2001). Vaccination of malignant glioma patients with peptide-pulsed dendritic cells elicits systemic cytotoxicity and intracranial T-cell infiltration. Cancer Research, Vol. 61, No. 3, (Feb 2001), pp. 842-847

Yu, JS., Liu, G., Ying, H., Yong, WH., Black, KL. \& Wheeler. CJ. (2004). Vaccination with tumor lysate-pulsed dendritic cells elicits antigen-specific cytotoxic T-cells in patients with malignant glioma. Cancer Research, Vol. 64, No. 14, Jul 2004), pp. 49734979

Yung, WK., Albright, RE., Olson, J., Fredericks, R., Fink, K., et al. (2000). A phase II study of temozolomide vs. procarbazine in patients with glioblastoma multiforme at first relapse. Br J Cancer, Vol. 83, No. 5, (Sep 2000), pp. 588-593

Zeng, J., Fournier, P. \& Schirrmacher, V. (2002). Induction of interferon-alpha and tumor necrosis factor-related apoptosis-inducing ligand in human blood mononuclear cells by hemaglutinin-neuraminidase but not $\mathrm{F}$ protein of Newcastle disease virus. Virology, Vol. 297, No. 1, (May 2002), pp. 19-30

Zhou, LJ. \& Tedder, TF. (1996). CD14+ blood monocytes can differentiate into functionally mature CD83+ dendritic cells. Proceedings of the National Academy of Sciences of the United States of America, Vol. 93, No. 6, (Mar 1996), pp. 2588-2592

Zobywalski, A., Javorovic, M., Frankenberger, B., Pohla, H., Kremmer, E. et al. (2007). Generation of clinical grade dendritic cells with capacity to produce biologically active IL-12p70. Journal of Translational Medicine, Vol. 12, No. 5, (Apr 2007), pp. 5-18 


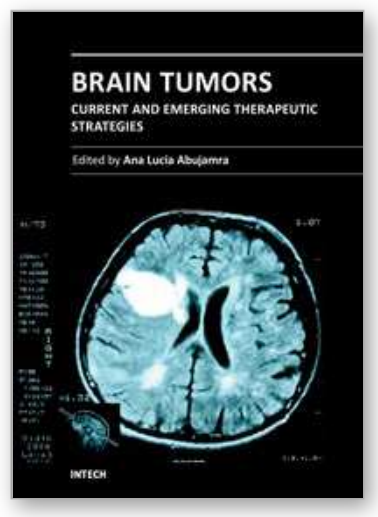

\author{
Brain Tumors - Current and Emerging Therapeutic Strategies \\ Edited by Dr. Ana Lucia Abujamra
}

ISBN 978-953-307-588-4

Hard cover, 422 pages

Publisher InTech

Published online 23, August, 2011

Published in print edition August, 2011

Brain Tumors: Current and Emerging Therapeutic Strategies focuses on tumor models, the molecular mechanisms involved in the pathogenesis of this disease, and on the new diagnostic and treatment strategies utilized to stage and treat this malignancy. A special section on immunotherapy and gene therapy provides the most up-to-date information on the pre-clinical and clinical advances of this therapeutic venue. Each chapter in Brain Tumors: Current and Emerging Therapeutic Strategies is authored by international experts with extensive experience in the areas covered.

\title{
How to reference
}

In order to correctly reference this scholarly work, feel free to copy and paste the following:

Thomas Neßelhut, Dagmar Marx, Jan Neßelhut and Fred Fändrich (2011). Immunotherapy with Dendritic Cells and Newcastle Disease Virus in Glioblastoma Multiforme, Brain Tumors - Current and Emerging Therapeutic Strategies, Dr. Ana Lucia Abujamra (Ed.), ISBN: 978-953-307-588-4, InTech, Available from: http://www.intechopen.com/books/brain-tumors-current-and-emerging-therapeutic-strategies/immunotherapywith-dendritic-cells-and-newcastle-disease-virus-in-glioblastoma-multiforme

\section{INTECH}

open science | open minds

\section{InTech Europe}

University Campus STeP Ri

Slavka Krautzeka 83/A

51000 Rijeka, Croatia

Phone: +385 (51) 770447

Fax: +385 (51) 686166

www.intechopen.com

\section{InTech China}

Unit 405, Office Block, Hotel Equatorial Shanghai

No.65, Yan An Road (West), Shanghai, 200040, China

中国上海市延安西路65号上海国际贵都大饭店办公楼405单元

Phone: +86-21-62489820

Fax: +86-21-62489821 
(C) 2011 The Author(s). Licensee IntechOpen. This chapter is distributed under the terms of the Creative Commons Attribution-NonCommercialShareAlike-3.0 License, which permits use, distribution and reproduction for non-commercial purposes, provided the original is properly cited and derivative works building on this content are distributed under the same license. 